\title{
Fostering corporate sustainability in the Mexican coffee industry
}

\author{
Nora Munguia, Alejandra Varela and Javier Esquer \\ Department of Industrial Engineering, University of Sonora, \\ Hermosillo, Mexico, and \\ Luis Eduardo Velázquez Contreras \\ Department of Industrial Engineering, University of Sonora, Hermosillo, Mexico, \\ and Department of Work Environment, University of Massachusetts Lowell, \\ Lowell, Massachusetts, USA
}

Mexican coffee industry

\begin{abstract}
Purpose - At the 21st Conference of the Parties to the United Nations Convention on Climate Change (COP 21) in Paris, 195 governments reached an agreement pivotal not only for countries but also for companies. The Paris Agreement makes it impossible to practice business as usual. The transition to a lowcarbon coffee industry could be achieved by fostering corporate sustainability. Accordingly, the purpose of this paper is to provide empirical evidence of how to adopt the principles of Paris Agreement by enhancing the corporate sustainability of a Mexican coffee-roaster company using the inventory phase of the life cycle assessment tool.
\end{abstract}

Design/methodology/approach - The data collection process followed the requirements of the International Reference Life Cycle Data System Handbook, developed by the Institute for Environment and Sustainability in the European Commission Joint Research Centre, and data on packaging materials and energy production were drawn from a commercially available database in the LCA software SimaPro.

Findings - Compiling data on the energy of the firm's material flows in a firm revealed opportunities to improve energy efficiency and to reduce greenhouse gas emissions. The results of the inventory analysis can be used to evaluate the specific environmental impacts of the coffee-roasting process at this Mexican coffee company. Data compilation activities for energy flows identified the need to install liquefied petroleum gas measuring devices and individual measuring devices for electricity consumption in different areas of the coffee plant. It is recommended that, while implementing this option, the company also develop an energy management program to achieve energy efficiency.

Practical implications - The inventory data in this case study permit comparisons of the current state of the system studied and its possible future states and offer stakeholders relevant information on resource use. Similarly, the project results provide the basis for future research on environmental performance in the coffee industry in Mexico and for the development of policies regarding the production process in the coffee supply chain. Consequently, this research can help fulfil Mexico's commitment to the Paris Agreement.

Social implications - Reaching the goal of the Paris Agreement will require gathering key information for each single company. The current case study has provided key data to foster the principles of sustainability in the Mexican coffee industry to help this sector to transit toward sustainable development, which is a new demand of the Mexican society. Even though it may seem simple, this is the hardest step for enhancing stakeholder involvement in corporate sustainability.

(C) Nora Munguia, Alejandra Varela, Javier Esquer and Luis Eduardo Velázquez Contreras. Published in the PSU Research Review: An International Journal. This article is published under the Creative Commons Attribution (CC BY 4.0) licence. Anyone may reproduce, distribute, translate and create derivative works of this article (for both commercial and non-commercial purposes), subject to full attribution to the original publication and authors. The full terms of this licence may be seen at http://creativecommons.org/licences/by/4.0/legalcode

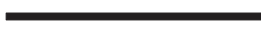


PRR

1,1

Originality/value - The main contribution of this research to science and practice is to confirm that fostering corporate sustainability is easier and more feasible when energy flow information is available.

Keywords Corporate sustainability, Coffee roasting, COP 21, Energy flows, Energy management system, Material flows.

Paper type Research paper

\section{Introduction}

The 21st Conference of the Parties to the United Nations Convention on Climate Change (COP 21), also called the Paris Agreement, offers real hope for addressing climate change in a timelier, responsible, unified, equitable and sustainable way (Roberts, 2016). One hundred and ninety-five countries signed this agreement to limit global temperature increases to less than $2^{\circ} \mathrm{C}$ as a minimum and to strive for $1.5^{\circ} \mathrm{C}$. However, it is questionable whether achieving these goals is possible. There are doubts as to whether the wording of the agreement, although admirable, sufficiently operationalizes the path toward the stated goal (Mesík, 2015).

The Paris Agreement certainly makes it impossible to do business as usual because society is demanding better corporate climate change strategies and disclosures (Haque and Azizul Ialam, 2015). Social demands, though, should be complemented with strict climate policy because this has positive effects on corporate efforts to reduce emissions (Cadez and Czerny, 2016). The incorporation of the principles of sustainability into a company's strategic planning is known as corporate sustainability. Sustainable development has replaced the traditional understanding of corporate performance as a solely the accumulation of capital for owners (Docekalová and Kocmanová, 2016). Stakeholder involvement is desirable to align company activities with the principles of sustainability but is often lacking (Schneider, 2015).

Companies make decisions concerning sustainability issues based on the information available, and managers have the responsibility to consider the best information. In the case of sustainability, decision makers face complex and ambiguous scenarios and consequently often do not make radical changes to foster corporate sustainability (Hahn et al., 2015). That companies prioritize profits in their decision-making should not be used as an excuse to take no action because it is also true that companies have a growing interest in developing environmentally friendly and healthy products (Edwards, 2009). Increasing profits while protecting the environment by reducing greenhouse gas (GHG) emissions is possible but presents a pressing need for industry strategies to ensure that all communities benefit from the transition to the jobs of the future, including communities and individuals reliant on fossil fuels for their livelihood (Nandy, 2016).

The coffee industry provides a good example of this new trend in which multinational retailers are the driving forces in the adoption of sustainability (Elder et al., 2014). Over the past decade, the coffee industry has been extremely profitable as the second-largest traded commodity in the world (Salomone et al., 2013). However, the industry has also been embroiled in several environmental controversies concerning the chain of production and consumption. For instance, the cultivation of coffee can deteriorate aquatic ecosystems, habitats and soil (Clay, 2004), and in the production and industrialization stages, the processing of coffee generates pollutants harmful to humans and the environment (Mussatto et al., 2011). Even during the roasting and consumption of the product, coffee waste can disrupt natural environments (Esquivel and Jiménez, 2012).

To adhere to the objectives of the Paris Agreement, the coffee industry must decrease its GHG emissions levels. However, this will be difficult because energy consumption in the production system is one of the most worrisome aspects of agricultural activity (De Lacerda Filho et al., 2014). The effective application of energy management in the production process 
has served as a catalyst for energy efficiency in the manufacturing industry (Bunse et al., 2011). Furthermore, initiatives developed by the United Nations Environmental Programme (UNEP, 2004), such as the Cleaner Production and Energy Efficiency Manual, provide a Mexican coffee detailed set of tools and worksheets to improve industrial environmental performance by reducing energy and resource consumption and harmful emissions.

The transition to a low-carbon coffee industry can be achieved by assessing GHG emissions through the industry's life cycle. Diverse methodologies have been used for this purpose. For instance, product carbon footprinting has been applied to evaluate the GHG emissions from the coffee supply chains and explore the industry's options to mitigate climate change (Noponen et al., 2012; Hassard et al., 2014). The life cycle of coffee has also been assessed using the quantitative material input per unit of service method and the semiquantitative hot-spot analysis method (Von Geibler et al., 2016).

Life cycle assessment (LCA) deserves special mention because it is a versatile tool that can be applied in different settings. LCA evaluates a product from a life cycle perspective and generates a detailed balance of the materials and energy needed for the production of the final product (Baumann and Tillman, 2004). This technique has been used to calculate the energy consumption and GHG emissions of several coffee-brewing methods, such as instant and traditional brewing (Humbert et al., 2009).

The first phase in LCA is goal and scope definition, which establishes the reasons for carrying out a study and establishes its spatial and time parameters (AENOR, 2006). Also, the functional unit is selected, and the system boundaries, data requirements and limitations are defined (De Bruijn et al. 2004). The second phase in LCA is the life cycle inventory (LCI), which consists of identifying the product system studied and compiling data on the input and output flows to determine the environmental impacts (Finnveden et al., 2009). In LCA, it is important to establish quality criteria for data collection and analysis during the LCI to ensure that the results accurately represent the state of the product system (Jiménez-González et al., 2000).

A practical contribution of the present study is to test the usefulness of LCA as a tool for compiling data on the energy and material flows of the production process for a coffeeroasting company, in this case, a company in the city of Hermosillo, Sonora, México. An inventory data set has been developed for this purpose. As in other countries, coffee is one of the most important crops in the Mexican agricultural sector (INEGI, 2013) and likely will remain so because home consumption of this product has increased in recent years, according to the International Coffee Organization (ICO, 2013). In this context, the purpose of this study is to provide empirical evidence on how to adopt the principles of Paris Agreement by improving the corporate sustainability of a Mexican coffee-roaster company using the inventory phase of the LCA tool.

\section{Materials and methods \\ Coffee-roasting process}

The studied company's production process for roasted coffee beans is presented in Figure 1. The first stage is storage, which begins with the reception of jute bags of green coffee beans delivered primarily from southern Mexico. Here, the identification and separation of bags take place. They are placed on different piles on wooden bases (pallets), identified and then wrapped in low-density polyethylene (LDPE) plastic for protection. Next, during the elevation stage, bags of green coffee beans are hand opened, emptied onto an elevator and screened to remove contaminants and debris. The green beans are transferred via an enclosed tubular drag cable conveyor to temporary hoppers for distribution in the next stage.

In the roasting stage, a batch roasting system uses liquefied petroleum gas (LPG) as fuel for heat generation in the gas burner. The desired temperature in this process is $260^{\circ} \mathrm{C}$. The 
PRR

1,1

roasting plant consists of three horizontal rotating roasting drums that tumble the green coffee beans in a current of hot combustion gases generated by the burner. Softened water is added to halt the roasting process, which lasts approximately $17 \mathrm{~min}$ and is controlled manually by operators. The beans are then transferred to a cooler basin, where they are stirred, and water is again manually added to facilitate the cooling process. Once cooled, the roasted coffee beans are transported by the conveyor to a hopper. Later, they are transferred to a control weighing scale for packaging in sealed polyethylene terephtalate (PET) bags. Bags of roasted coffee beans are placed in cardboard boxes covered with LDPE for distribution.

The data were collected during the reference year 2013-2014 with an average annual production of 2,300 tons of packaged, roasted coffee beans. The operating parameters of the three roasters are presented in Table I.

The data collection process in this LCI followed the requirements of the International Reference Life Cycle Data System Handbook (ILCD), developed by the Institute for Environment and Sustainability in the European Commission Joint Research Centre (EU-JRC-IES, 2010) to ensure the quality of information (Table II). The data parameters identified for each unit process within the system boundaries are the material and energy input; water intake; product and material output; and air, water and soil emissions related to the annual production of 2,300 tons of roasted coffee beans. Data on packaging materials and energy production were drawn from a commercially available database in the LCA software SimaPro (PRé, 2013).

The scope of this project was a gate-to-gate study of the manufacturing process for roasted coffee beans. The system boundaries are shown in Figure 2 and are defined to include the processing of green beans for the production of packaged, roasted coffee beans ready for distribution. The cultivation of coffee beans was excluded from the system due to limited available data. The production of the equipment used was also excluded from the system. The functional unit selected was the firm's annual production of packaged, roasted coffee ready for distribution to the consumer in the reference year of 2013-2014 and was defined as 2,300 tons of packaged, roasted coffee beans.

The inventory data on material and energy flows were obtained on site. Interviews and surveys were conducted with plant supervisors and operators to gain information on the

Figure 1. Coffee-roasting process

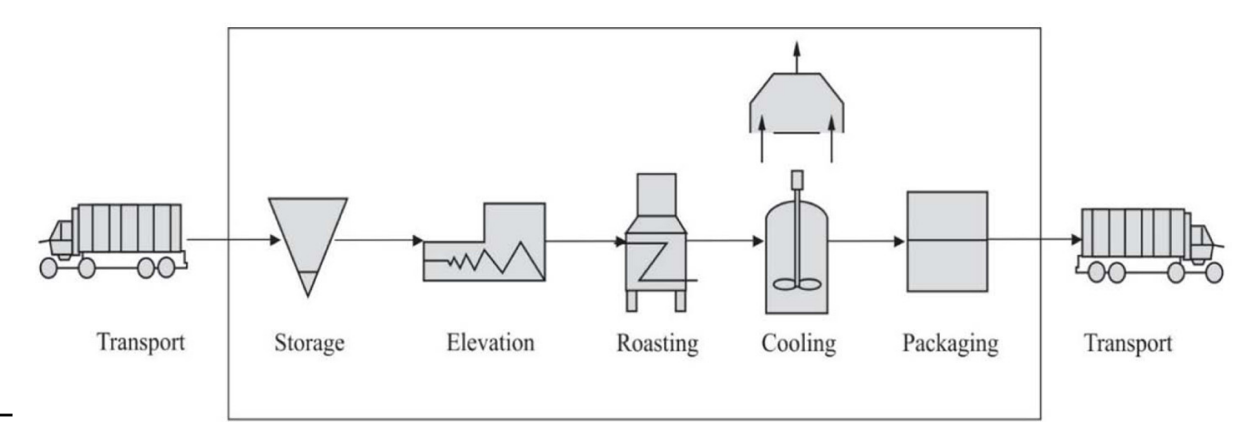

\begin{tabular}{cclc}
\hline Roaster & Installation year & Specifications & Capacity (kg) \\
\hline 1 & 2012 & Gas burner with low emission of nitrogen oxides (NOx) & 290 \\
2 & 2008 & Gas burner with low emission of NOx & 290 \\
3 & 2009 & Gas burner with low emission of NOx & 290 \\
\hline
\end{tabular}

\section{Table I.} Operating parameters for the coffee roasters

. 
Technological representativeness Degree to which the data set reflects the true population of interest regarding technology

Geographical representativeness

Degree to which the data set reflects the true population of interest regarding geography

Time-related representativeness

Degree to which the data set reflects the true population of interest industry

Completeness regarding time/age of the data

Precision/uncertainty Share of flows that are quantitatively included in the inventory

Methodological appropriateness Measure of the variability of the data values for each data expressed and consistency The applied LCI methods and methodological choices are in line with the goal and scope of the data set

Table II.

Overview on LCI data quality

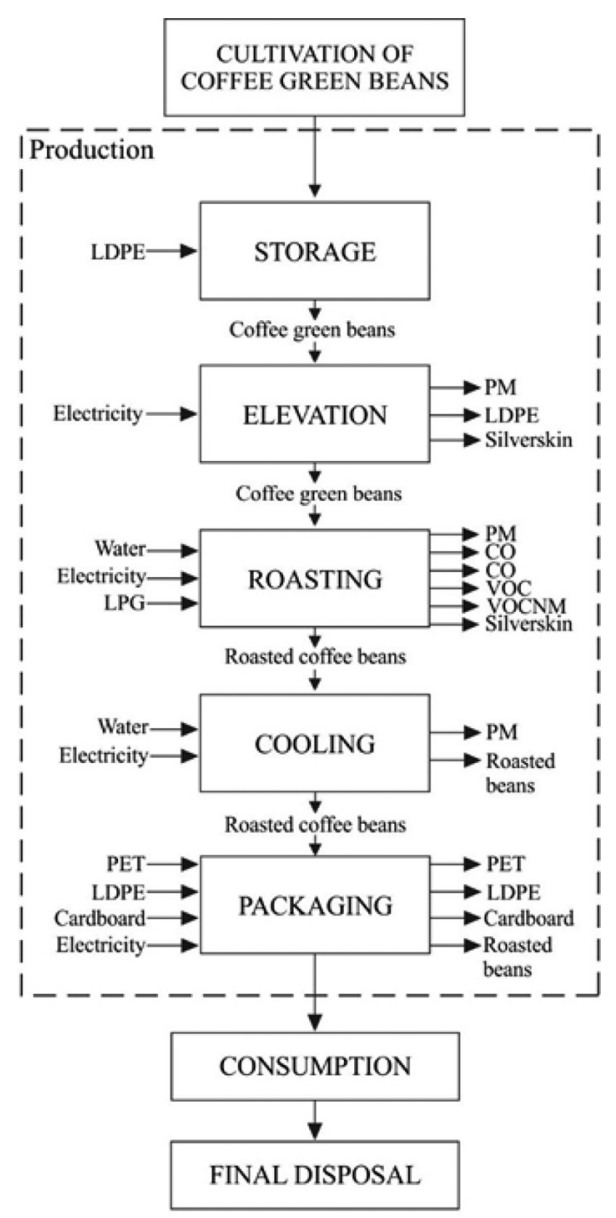

Figure 2.

Life cycle of coffee and system boundaries 
PRR

1,1

\section{6}

processes, logistics and equipment of the studied system. Data on material inputs were based on annual totals measured by the firm. Company staff estimated LPG consumption data because instruments to measure actual LPG use were not available. Measurements of electricity consumption for the production process were not available, and estimates should be obtained for relevant missing data. Therefore, energy consumption estimates for each piece of electrical equipment were calculated using equation (1) from the United States Department of Energy (U.S. DOE, 2014):

$$
E=(W \times \text { Hours }) / 1000
$$

where $E$ is the annual energy consumption in $\mathrm{kWh}, W$ is the rated power consumption of the machinery in watts and Hours represents the annual hours of machinery use.

For waste flows, on-site segregation and daily weighing for each stage of the process was done. Regarding air emissions during the roasting stage, emission factors were used, along with site-specific measures provided by the company. The emission factors used are listed in Table III and were based on calculations concerning the equipment and technology used in the process by the US Environmental Protection Agency (EPA, 1972,1995) and the national GHG inventory from Mexico (Sheinbaum and Ozawa, 2006). Data on air emissions from the roasting process were calculated using equation (2) (SEMARNAT-INECC, 2013a):

$$
\text { Emission }\left[S_{1}\right]=E F \times P
$$

where $S 1$ is the substance of interest, $E F$ is the emissions factor for the specified conditions and $P$ represents a production capacity of $2,300,000 \mathrm{~kg}$ of roasted coffee beans.

Company data also covered emission fluxes that follow the Official Mexican Standard NOM-085-SEMARNAT-2011 (2011) criteria for determining carbon monoxide and carbon dioxide $\left(\mathrm{CO}_{2}\right)$ emissions, as given in equation (3):

$$
\text { Emission }\left[S_{2}\right]=E R \times R_{h}
$$

where $S 2$ is the substance of interest, $E R$ is the emission rate of the substance in the process and $R h$ is the operating hours of the roasters in the production of 2,300,000 $\mathrm{kg}$ of roasted coffee beans.

\section{Results and discussion}

The compilation of data on the energy and material flows in this case study revealed interesting opportunity areas for reducing costs and GHG emissions. Moreover, it generated information valuable to fostering corporate sustainability in this firm.

\begin{tabular}{llc}
\hline Stage & Substance & Emission factor (kg/kg beans) \\
\hline Elevation & Particulate matter (PM) Filterable & $0.0000267^{\mathrm{a}}$ \\
Roasting & PM filterable & $0.0019^{\mathrm{a}}$ \\
& VOCs non-methane (VOCNM) & $0.0006^{\mathrm{b}}$ \\
Cooling & VOC (Methane) & $0.00039^{\mathrm{a}}$ \\
& PM filterable & $0.0000127^{\mathrm{a}}$ \\
& & \\
\hline
\end{tabular}

Table III.

Emission factors for the coffee-roasting process

${ }^{\mathrm{a}}$ EPA $(1972,1995) ;$ ' Sheinbaum and Ozawa (2006) 
Table IV shows the results for the coffee company's electrical energy consumption estimates for each process stage. The main electrical energy consumer is the roasting stage, which uses a very large amount of electricity, in addition to LPG. This high consumption is Mexican coffee industry attributed to the use of air exhaust fans at the three roasting stations installed at the plant. Research has shown that energy efficiency programs can provide companies with economic benefits by reducing energy costs and increasing productivity (Worrell et al., 2003). Other authors, however, suggest that barriers to the implementation of energy efficiency technologies and programs persist in firms, despite knowledge of the potential benefits of these measures (Cagno et al., 2013).

The inventory data on the energy and material flows for the production of 2,300 tons of packaged, roasted coffee beans in the reference year 2013-2014 are shown in Table V. The air emission results show that the main air pollutants in this case study are $\mathrm{CO}_{2}(462,000 \mathrm{~kg})$ and particulate matter (PM10) (6,900 kg), while volatile organic compounds (VOC), non-methane, sulfur dioxide and methane are also released in lesser quantities. These results agree with the findings of De Monte et al. (2003) that the main air emissions from the coffee roasting and cooling processes are PM, CO2, VOCs, nitrogen oxide and sulfur oxide. Additionally, some exhaust gases responsible for the characteristic smell of coffee emitted during the cooling stage are acetaldehyde, pyridine, pyrazine and acetic acid (Ranau and Steinhart, 2005).

As mentioned, the main air pollutant resulting from coffee roasting in this case study is $\mathrm{CO}_{2}$. Globally, $\mathrm{CO}_{2}$ is categorized as the most important GHG in need of being reduced (Smith et al., 2013). Consequently, a great number of institutions and organizations are dedicated to the reduction of GHG emissions as a strategy to mitigate climate change (SEMARNAT-INECC, 2013b). Mexico's national agenda supports this goal. In particular, the General Law on Climate Change has established a commitment to decrease GHG emissions by 30 per cent by 2020 and 50 per cent by 2050 (DOF, (2012)). For Mexican industries, voluntarily adopting environmental programs could reduce GHG emissions, despite a lack of relevant regulation (Henriques et al., 2013).

The absence of site-specific pollutant measurements for every substance resulted in estimates based on pre-established emission factors. This points to the need for the coffee company to identify and continuously measure exhaust gases to improve pollution control and reduce or eliminate air emissions.

Regarding PM and exhaust gases from the roasting process, the literature shows that the installation of abatement technology can minimize emissions. First, installing cyclones and filters for PM collection is recommended. Second, for CO and VOC emissions, the most widely discussed recommendation is to install thermal or catalytic oxidizers (Schmidt, 2008). Third, flameless regenerative thermal oxidation technology can reduce emissions from pollutant oxidation and energy consumption in coffee roasting by using exhaust gas heat from the roaster (Lange et al., 2009).

In the case study, the outflows for the roasting process show that the major solid wastes generated are coffee silverskin (11,000 kg) and LDPE and PET plastics (520 and $880 \mathrm{~kg}$, respectively). The firm has an established system to segregate, collect, ship and sell

Stage

Energy consumption (kWh/Functional Unit)

Elevation

Table IV.

Energy consumption by process stage 


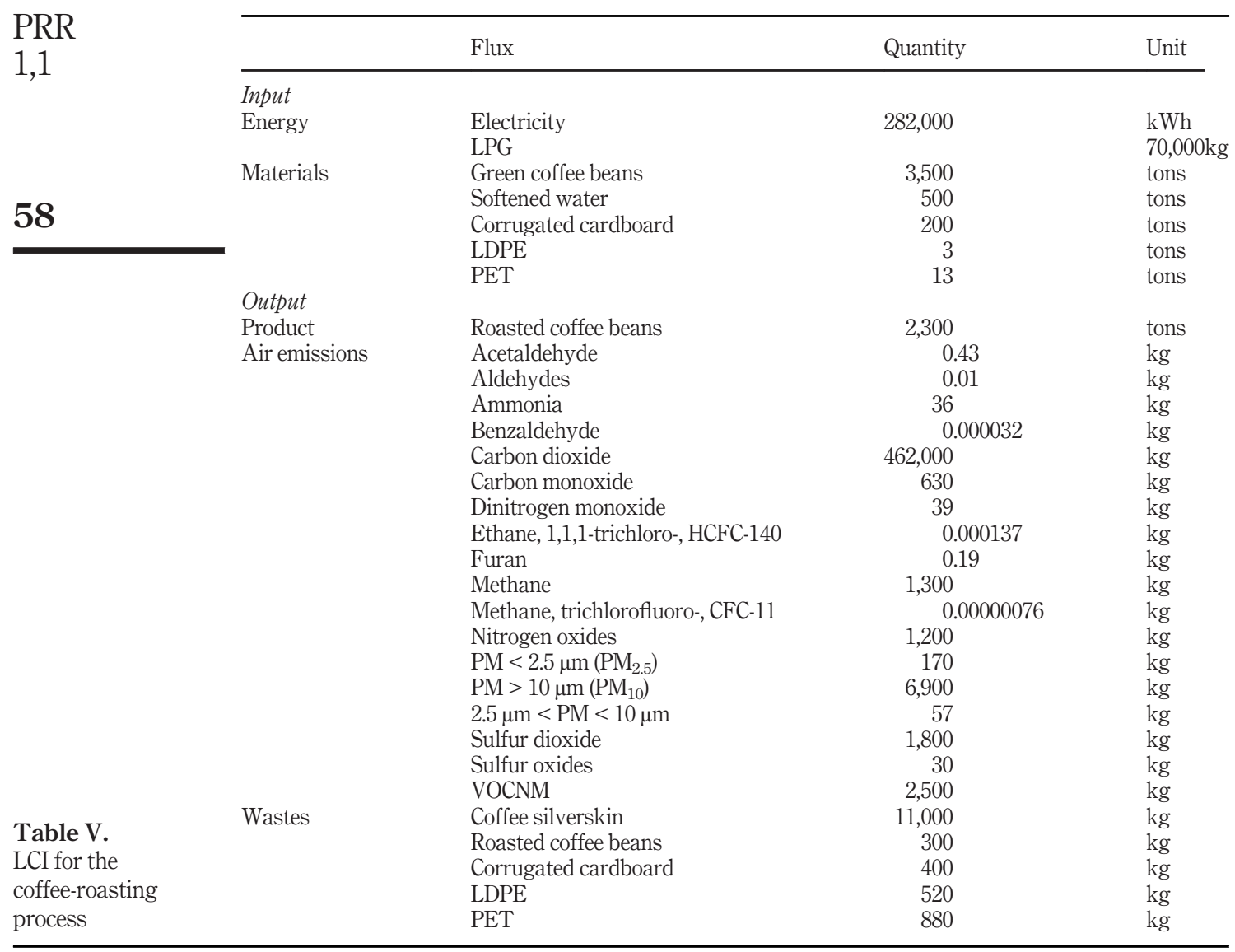

recoverable waste to an external recycling company. However, a fraction of recoverable material is not recycled due to operators' failure to segregate the waste.

The use of coffee byproducts to improve sustainability is relatively new to the coffee industry in Mexico, although many studies support its effectiveness (Wong et al., 2013). Some studies report that coffee silverskin contains antioxidant properties that the chemical industry can exploit to manufacture food supplements and beauty products (Yen et al., 2005; Napolitano et al., 2007; Costa et al., 2014). Coffee silverskin extract has also been found to be a potential source for the production of diet beverages (Martinez-Saez et al., 2014). Other authors suggest that it is possible to produce a low-cost magnetic biosorbent for wastewater treatment due to its high fiber and protein content (Zuorro and Lavecchia, 2013).

Considering coffee silverskin as a byproduct instead of waste could enable the roasting company to open a new market and increase its profits by selling coffee silverskin as raw material for other production processes, minimizing the company's negative ecological impact. However, more research on the economic feasibility of the industrial use of coffee silverskin is needed (Narita and Inouye, 2014).

Additionally, the literature review showed that data on emissions and waste in the coffee-roasting process in Mexico are very limited, and emission factors developed in the 
USA might be inaccurate when applied to the Mexican industry. Therefore, it is important to conduct research in this area to broaden the national database on industrial processes based on the criteria established by international standards, such as the ILCD.

Finally, it should be highlighted that, before this study, there was a lack of inventory data on this coffee process in the country. The study findings then make a valuable contribution to the actual LCA knowledge stock in Mexico, which has positive implications for research and practice.

\section{Conclusions}

When Mexico signed the Paris Agreement, it indicated its commitment to develop a roadmap to limit global warming to less than $2^{\circ} \mathrm{C}$ by 2100 , but this goal will only be achieved if most companies embrace corporate sustainability. The main contribution of this research to science and practice is to confirm that fostering corporate sustainability is easier and more feasible when information is available. In this case study, compiling data on the energy of material flows helps reveal opportunities not only to improve energy efficiency but also to reduce GHG emissions.

The results of the inventory analysis have the potential to be used with the LCA tool to evaluate specific environmental impacts caused by the coffee-roasting process at this Mexican coffee company. Compilation of data on energy flows identifies the need to install LPG measuring devices and individual measuring devices for electricity consumption in various areas of the coffee plant. In addition to this option, it is recommended that the company implement an energy management program to achieve energy efficiency.

The annual production of 2,300 tons of roasted coffee results in emissions of GHG during the roasting stage and PM in several stages. More efficient abatement technology should be installed to further reduce air emissions. Additionally, the site-specific emission substances for each stage of the roasting process should be characterized to elevate the company's view of environmental protection from basic compliance with Mexican regulations to continuous improvement in the production process.

The inventory data in this case study permit comparisons of the current state of the system studied and its possible future states and offer stakeholders relevant information on resource use. Similarly, the project results provide the basis for future research on environmental performance in the coffee industry in Mexico and for the development of policies regarding the production process in the coffee supply chain. Consequently, this research can help fulfil Mexico's commitment to the Paris Agreement.

\section{Compliance with ethical standards}

Disclosure of potential conflicts of interest: All authors declare that no potential conflict of interest exists.

Ethical approval: This article does not contain any studies with human participants or animals performed by any of the authors.

Informed consent: Informed consent was not necessary for this study.

\section{References}

AENOR (2006), Principios y Marco de Referencia, Asociación Española de Normalización y Certificación, ISO 14040:2006.

Baumann, H. and Tillman, A. (2004), The Hitch Hiker's Guide to LCA, An Orientation in Life Cycle Assessment Methodology and Application, Studentlitteratur AB. 
PRR

1,1

Bunse, K., Vodicka, M., Schönsleben, P., Brülhart, M. and Ernst, F.O. (2011), "Integrating energy efficiency performance in production management - gap analysis between industrial needs and scientific literature", Journal of Cleaner Production, Vol. 19 Nos 6/7, pp. 667-679.

Cadez, S. and Czerny, A. (2016), "Climate change mitigation strategies in carbon-intensive firms", Journal of Cleaner Production, Vol. 112, pp. 4132-4143.

Cagno, E., Worrell, E., Trianni, A. and Pugliese, G. (2013), "A novel approach for barriers to industrial energy efficiency", Renewable \& Sustainable Energy Reviews, Vol. 19, pp. 290-308.

Clay, J. (2004), World Agriculture and the Environment: A Commodity-By-Commodity Guide to Impacts and Practices, Island Press, Washington, DC.

Costa, A., Alves, R., Vinha, A., Barreira, S., Nunes, M., Cunha, L. and Oliveira, M. (2014), "Optimization of antioxidants extraction from coffee silverskin, a roasting by-product, having in view a sustainable process", Industrial Crops and Products, Vol. 53, pp. 350-357.

De Bruijn, H., Van Duin, R. and Huijbregts, M. (2004), "Management of LCA projects: procedures", in Guinee, J., Gorree, M., Heijungs, R., Huppes, G., Kleijn, R., Koning, A., Oers, L., Wegener Sleeswijk, A., Suh, S. and Udo de Haes, H. (Eds), Handbook on Life Cycle Assessment, Springer, Netherlands.

De Lacerda Filho, A., Fonseca, J., Jimenez de Almeida, R., Ribeiro, A. and de Castro Melo, E. (2014), "Energy balance in the production of mountain coffee", Renewable and Sustainable Energy Reviews, Vol. 39, pp. 1208-1213.

De Monte, M., Padoano, E. and Pozzetto, D. (2003), "Waste heat recovery in a coffee roasting plant", Applied Thermal Engineering, Vol. 23 No. 8, pp. 1033-1044.

Docekalová, M. and Kocmanová, A. (2016), "Composite indicator for measuring corporate sustainability", Ecological Indicators, Vol. 61, pp. 612-623.

DOF (2012), "Ley general de Cambio Climático", in CDDHCU (Ed.), Diario Oficial de la Nación, México.

Edwards, S. (2009), A New Way of Thinking: The Lowell Center Framework for Sustainable Products, University of Massachusetts Lowell, Lowell, MA.

Elder, S., Lister, J. and Dauverne, P. (2014) "Big retail and sustainable coffee: a new development studies research agenda", Progress in Development Studies, Vol. 14 No. 1, pp. 77-90.

EPA (1972), Compilation of Air Pollutant Emission Factors, 2nd ed., Environmental Protection Agency, North Carolina, NC.

EPA (1995), Compilation of Air Pollutant Emission Factors, 5th ed., Environmental Protection Agency, North Carolina, NC.

Esquivel, P. and Jiménez, V.M. (2012), "Functional properties of coffee and coffee by-products", Food Research International, Vol. 46 No. 2, pp. 488-495.

EU-JRC-IES (2010), European Commission - Joint Research Centre - Institute for Environment and Sustainability: International Reference Life Cycle Data System (ILCD) Handbook - General guide for Life Cycle Assessment - Detailed guidance, 1st ed., Luxembourg.

Finnveden, G., Hauschild, M.Z., Ekvall, T., Guinée, J., Heijungs, R., Hellweg, S., Koehler, A., Pennington, D. and Suh, S. (2009), "Recent developments in life cycle assessment", Journal of Environmental Manage, Vol. 91 No. 1, pp. 1-21.

Hahn, T, Preuss, L., Pinkse, J. and Figge, F. (2015), "Cognitive frames in corporate sustainability: managerial sense making with paradoxical and business case frames", Academy of Management Review, Vol. 4015 No. 1, pp. 18-42.

Hassard, H.A., Couch, M.H., Techa-Erawan, T. and Mclellan, B.C. (2014), "Product carbon footprint and energy analysis of alternative coffee products in Japan", Journal of Cleaner Production, Vol. 73, pp. 310-321.

Haque, S. and Azizul Islam, M. (2015), "Stakeholder pressures on corporate climate change-related accountability and disclosures: Australian evidence", Business and Politics, 17(2), pp. 355-390. 
Henriques, I., Husted,B.W. and Montiel, I. (2013), Spillover effects of voluntary environmental programs on greenhouse gas emissions: lessons from Mexico, Journal of Policy Analysis and Management, Vol. 32 No. 2, pp. 296-322.

Humbert, S., Loerincik, Y., Rossi, V., Margni, M. and Jolliet, O. (2009), Life cycle assessment of spray dried soluble coffee and comparison with alternatives (drip filter and capsule espresso), Journal of Cleaner Production, Vol. 17 No. 15, pp. 1351-1358.

ICO (2013), Outlook for the World Coffee Market, International Coffee Organization, Belo Horizonte.

INEGI (2013), El sector alimentario en México 2013, Serie Estadísticas Sectoriales, Instituto Nacional de industry Estadística y Geografía, México.

Jiménez-González, C., Kim, S. and Overcash, M. (2000), Methodology for developing gate-to-gate life cycle inventory information, International Journal of Life Cycle Assessment, Vol. 5 No. 3, pp. 153-159.

Lange, S., Jansen, G.A. and Moeller-Willenberg, U. (2009), "Roasting device for vegetable bulk material and method for operating a roasting device for vegetable bulk material", Google Patents.

Martinez-Saez, N., Ullate, M., Martin-Cabrejas, M., Martorell, P., Genovés, S., Ramon, D., and del Castillo, M. (2014), A novel antioxidant beverage for body weight control based on coffee silverskin, Food Chemistry, Vol. 150, pp. 227-234.

Mesík, J. (2015), Paris climate change agreement: a milestone or a fake?, International Issues \& Slovak Foreign Policy Affairs, Vol. 24 No. 4, pp. 79-98.

Mussatto, S., Machado, E.S., Martins, S. and Teixeira, J. (2011), Production, composition, and application of coffee and Its industrial residues, Food and Bioprocess Tech, Vol. 4, pp. 661-672.

Nandy, L. (2016), What is the significance of the Paris agreement?, Renewal, Vol. 24 No. 1.

Napolitano, A., Fogliano, V., Tafuri, A. and Ritieni, A. (2007) Natural occurrence of ochratoxin a and antioxidant activities of green and roasted coffees and corresponding byproducts, Journal of Agricultural and Food Chemistry, Vol. 55 No. 25, pp. 10499-10504.

Narita, Y. and Inouye, K. (2014), Review on utilization and composition of coffee silverskin, Food Research International, Vol. 61, pp. 16-22.

NOM-085-SEMARNAT-2011 (2011), Contaminación Atmosférica: Niveles Máximos Permisibles de Emisión de los Equipos de Combustión de Calentamiento Indirecto y su Medición, Secretaria de Economía, México.

Noponen, M., Edwards-Jones, G., Haggar, J., Soto, G., Attarzadeh, N. and Healey, J. (2012), Greenhouse gas emissions in coffee grown with differing input levels under conventional and organic management, Agriculture, Ecosystems and Environment, Vol. 151, pp. 6-15.

PRé (2013), SimaPro 8 [Online], PRé, Amersfoort, available at: www.pre-sustainability.com/simapro

Ranau, R. and Steinhart, H. (2005), Identification and evaluation of volatile odor-active pollutants from different odor emission sources in the food industry, European Food Research and Technology, Vol. 220 No. 2, pp. 226-231.

Roberts, D. (2016), A global roadmap for climate change action: from COP17 in Durban to COP21 in Paris, South African Journal of Science, Vol. 112, pp. 1-3.

Salomone, R., Ioppolo, G. and Saija, G. (2013), The Implementation of Product-Oriented Environmental Management Systems in Agri-Food SMEs Product-Oriented Environmental Management Systems (POEMS), Springer Science+Business Media, Dordrecht.

Schmidt, K. (2008), Mitigating the Environmental Impact of Coffee Roasting, NCA Convention: National Coffee Association, New York, NY.

Schneider, A. (2015), Reflexivity in sustainability accounting and management: transcending the economic focus of corporate sustainability, Journal of Business Ethics, 127, 525-536.

SEMARNAT-INECC (2013a), Guia Metodológica Para la Estimación de Emisiones de Fuentes Fijas. Secretaría de Medio Ambiente y Recursos Naturales, Instituto Nacional de Ecología y Cambio Climático, México. 
PRR

1,1

SEMARNAT-INECC (2013b), Inventario Nacional de Gases de Efecto Invernadero 1990-2010. Secretaría de Medio Ambiente y Recursos Naturales, Instituto Nacional de Ecología y Cambio Climático, México.

Sheinbaum, C. and Ozawa, L. (2006), Inventario Nacional de Gases de Efecto Invernadero, Instituto de Ingeniería UNAM, México.

Smith, K.R., Desai, M.A., Rogers, J.V. and Houghton, R.A. (2013), "Joint CO2 and CH4 accountability for global warming", Proceedings of the National Academy of Sciences of the United States of America, Vol. 110 No. 31, pp. E2865-E2874.

U.S. DOE (2014), "Estimating appliance and home electronic energy use online", U.S. Department of Energy, available at: http://energy.gov/energysaver/articles/estimating-appliance-and-homeelectronic-energy-use (accessed 29 September 2014).

UNEP (2004), Guidelines for the Integration of Cleaner Production and Energy Efficiency, United Nations Environment Programme.

Von Geibler, J., Cordaro, F., Kennedy, K., Lettenmeier, M. and Roche, B. (2016), "Integrating resource efficiency in business strategies: a mixed-method approach for environmental life cycle assessment in the single-serve coffee value chain", Journal of Cleaner Production, Vol. 115, pp. $62-74$.

Wong, J., Guyot, S., Rodríguez, R., Gutiérrez, G., Contreras, J., Saucedo, G. and Aguilar, C. (2013), Alternativas Actuales Para El Manejo Sustentable De Los Residuos De La Industria Del Café En México Acta Química Mexicana, UAC, Coahuila, México.

Worrell, E., Laitner, J.A., Ruth, M. and Finman, H. (2003), "Productivity benefits of industrial energy efficiency measures", Energy, Vol. 28, pp. 1081-1098.

Yen, W.J., Wang, B.S., Changn, L.W. and Duh, P.D. (2005), "Antioxidant properties of roasted coffee residues", Journal of Agricultural and Food Chemistry, Vol. 53 No. 7, pp. 2658-2663.

Zuorro, A. and Lavecchia, R. (2013), "Preparation and characterization of magnetically responsive biosorbents from coffee industry residues", Applied Mechanics and Materials, Vol. 394, pp. 3-7.

\section{Further reading}

Nikbakhsh, E. (2009), "Green supply chain management", in Zanjirani Farahani, R., Asgari, N. and Davarzani, H. (Eds), Supply Chain and Logistics in National, International and Governmental Environment, Physica-Verlag, HD.

\section{Corresponding author}

Luis Eduardo Velázquez Contreras can be contacted at: Luis_Velazquez@industrial.uson.mx

For instructions on how to order reprints of this article, please visit our website: 